\title{
A SEMIOTIC ANALYSIS ON THE PERCEIVED MEANINGS OF COCA COLA "ANTHEM" VIDEO COMMERCIAL
}

\author{
Melita Leo, Esther Harijanti Kuntjara \\ English Department, Faculty of Letters, Petra Christian University Surabaya, East Java, Indonesia \\ e-mail: melitaliauw@gmail.com, estherk@petra.ac.id
}

\begin{abstract}
This study observes the perceived meanings produced by young adult (18 to 30 years old) and older (50 to 65 years old) respondents as respondents from different age group can produce different perceived meanings from each other. The writer's finding is that in perceiving, young adult respondents tend to emphasize on Coca Cola's emotional roles. On the other hand, the older respondents emphasize on Coca Cola's physical roles.
\end{abstract}

Key words: Process of Signification, Sign, Signifier, Signified, Perceived Meaning.

\section{INTRODUCTION}

Advertisement is one of the essential tools a company should have in today's business world where marketing communication is applied everywhere. According to Harris (2004), advertisement tries to affect or alter the reality of the audience, in the sense that advertisement is designed to establish a new image or point of view regarding a certain product. In a way, advertisement has been considered as one of the greatest tool in both introducing and promoting a product today.

Some companies have successfully managed to create interactive advertisements that allow them to create new customers and retain loyal customers that stick with them for years. These companies' advertisements have enabled their customers to be aware of their products' existence. A good example of companies that successfully create such advertisement is none other than The Coca Cola Company. There is no doubt that Coca Cola has remained as the top in their industry and they continue to reinforce their brand with their unique and innovative ways. Making a change in their marketing strategy this January 2016, Coca Cola released a total of six 60 -second advertisements under one global creative campaign, which is: Taste the Feeling. For her research, the writer used one of the videos called "Anthem" as it is the lead video for Coca Cola's campaign in 2016.

As we know, advertising has become pillars for all successful businesses all over the world, Coca Cola included. Nonetheless, the effectiveness of advertising depends on how the customers proccess, digest, or perceive the information and messages given in the advertisements. Certainly, not all customers get the same message when watching one advertisements. One of the factors that affects the way customers process information is age (Fung and Carstensen (2003); Williams and Drolet (2005)) because compared to young adults, the elderly emphasizes more on personal experiences and values. Thus, their emphasis affects their process of perceiving the information given.

Based on the explanation above, the writer's research seeks to discover the young adult and older viewers' perceived meanings of Coca Cola "Anthem" video commercial. The writer is intrigued to do a research about viewers' perceived meaning in Coca Cola "Anthem" video commercial because viewers from different ages can perceive meaning completely different from each other.

As the writer wants to examine young adult and older viewers' perceived meanings, the writer used process of signification including connotation, denotation, myth as well as Peirce's three sign modes as her main theories. For process of signification, the writer used theory from C.S. Peirce written by Daniel Chandler (Chandler, 2007). The writer also used and applied Daniel Chandler's (2007) theory about myth. Lastly, the writer uses Peirce's three sign modes (symbolic, iconic, and indexical mode) which are renewed by Chandler (2007) to analyze how meaning is perceived in the video advertisement.

\section{METHODS}


The writer analyzed by using descriptive qualitative approach since the writer's research aims to describe perceived meanings of a Coca Cola's advertisement under "Taste the Feeling" campaign. Qualitative approach is appropriate for this reseach as the writer is interested in individual interpretation and reactions to the object of investigation. Furthermore, descriptive qualititave approach is the most suitable for this research as it describes the meaning of qualitative material in a systematic way (Schreier, 2012, p.1).

The writer chose one out of six Coca Cola Taste the Feeling videos for her research. According to Marcos de Quinto, Chief Marketing Officer, 'Taste the Feeling' is a "one brand" approach which reinforces that Coca Cola is a brand with various variants sharing the same values and icon. The campaign is intended to send a message to their customers, which is whichever Coca Cola they drink, with or without calories, with or without caffeine, Coca Cola can fit to any of the customers' taste, diet, and lifestyle. The campaign also emphasizes that Coca Cola is for everybody, that Coca Cola is not limited for particular group of customers. The video the writer wanted to analyze is representative in terms of the campaign message. Therefore, the writer limited her source of data to Coca Cola "Anthem" video commercial. The writer herself is the main instrument of this research since she was the one who both collected and analyzed the data from the source mentioned before.

In this research, the writer chose 16 respondents consisting of eight young adult (age 18 to 30 years old) and eight older repondents (age 50 to 65 years old). The young adult respondents involved are mostly university students and one office worker. The older respondents involved in this study are mostly business people and a lecturer. In interviewing the respondents, the writer used semi-structured questionnaires to get more of the respondents' views on the video commercial. In asking the older respondents who do not understand English, the writer translated the words to Indonesian. The writer obtained the Indonesian translation from the official Indonesian version of the video commercial.

The writer prepared a total of 19 questions for the interview session. The writer used the first four questions (Interview question no. $1-4$ ) as an opening and an ice breaker. The writer also wanted to know the respondents' daily consumption of Coca Cola. After that, the writer continued with asking questions regarding the verbal data. The writer decided to ask the selected verbal data first because the writer wanted to see whether the respondents understand Coca Cola's message just from the verbal data as the verbal data in the video plays a great role in conveying the message. Then, the writer proceeded with asking the respondents' opinion regarding the selected non-verbal data. After interviewing all of the designated respondents, the writer started transcribing each respondent's interview session and continued with her analysis.

\section{ANALYSIS AND FINDINGS}

In order to answer the research questions, the writer analyzes two elements of every respondent's perceived meanings, such as:

- Selected verbal data (Interview question no 7 - 11) for each respondent

- Selected non-verbal data (Interview question no $14-18$ ) for each respondent

\section{The analysis of perceived meanings by young adult respondents}

The young adult respondents are classified as Respondent no 1 to 8 (R1 to R8). From the data of young adult respondents, the writer discovered that some respondents produced similar perceived meanings. In the analysis, the writer grouped similar perceived meanings into one unit of analysis. There is also one respondent that may have different perceived meanings from other respondents. In this case, the writer analyzed the respondent independently. The writer sorted her analyses by starting from the largest group of similar perceived meanings to individual's perceived meaning.

\section{The analysis of young adult respondents' perceived meanings from the verbal data}

In order to answer her research question, the writer analyzed each respondent's perceived meanings from five specific verbal data which was chosen by the writer herself. To summarize her 
findings, here the writer has classified young adult respondents' perceived meanings from the verbal data in one table:

Table 1: Young adult respondents' verbal data perceived meanings

\begin{tabular}{|c|c|}
\hline Verbal data & Young Adult Respondents \\
\hline $\begin{array}{l}\text { "Friends with } \\
\text { Stories" }\end{array}$ & $\begin{array}{l}\text { - No relation to Coca Cola } \\
\text { - A situation when we hang out with friends } \\
\text { - Coca Cola as a means to share something } \\
\text { - Coca Cola deepen friendship } \\
\text { - Coca Cola produces more colorful friendship }\end{array}$ \\
\hline $\begin{array}{l}\text { "Smiles with } \\
\text { Secrets" }\end{array}$ & $\begin{array}{l}\text { - A situation when we share secrets to our friends } \\
\text { - No relation to Coca Cola } \\
\text { - Coca Cola helps us smile } \\
\text { - Coca Cola as an ice breaker }\end{array}$ \\
\hline $\begin{array}{l}\text { "Love with } \\
\text { Refresh" }\end{array}$ & $\begin{array}{l}\text { - Coca Cola gives refreshing feeling } \\
\text { - Coca Cola brings freshness and love } \\
\text { - Coca Cola as an ice breaker } \\
\text { - Coca Cola makes us closer to our friends } \\
\text { - A situation showing a relationship between the boy } \\
\text { - } \quad \text { No relation to Coca Cola }\end{array}$ \\
\hline $\begin{array}{c}\text { "Strangers with } \\
\text { Fire" }\end{array}$ & $\begin{array}{l}\text { - } \quad \text { Coca Cola can connect us with strangers } \\
\text { - No relation to Coca Cola } \\
\text { - Describing a common process of meeting a stranger }\end{array}$ \\
\hline $\begin{array}{l}\text { "Madness with } \\
\text { You" }\end{array}$ & $\begin{array}{l}\text { - Coca Cola encourages us to something crazy with } \\
\text { - } \text { Comeone special } \\
\text { - Madness shared with someone closest to us } \\
\text { - A situtation where we are willing to do anything for } \\
\text { someone special }\end{array}$ \\
\hline
\end{tabular}

In perceiving the verbal data, the young adult respondents always tried to relate the words and the picture shown along with the words. The writer saw that the picture had helped the respondents in perceiving the verbal data. In giving perceived meanings, the young adult respondents also related the words with their own personal experiences with their friends and their own culture. Although most of the young adult respondents are not fans of Coca Cola, they easily related the words to Coca Cola itself.

\section{The analysis of young adult respondents' perceived meanings from the non-verbal data}

For the non-verbal data, the writer also chose five specific pictures for the respondents to give reactions to. Here the writer has also classified young adult respondents' perceived meanings from the non-verbal data in one table:

Table 2: Young adult respondents' non-verbal data perceived meanings

\begin{tabular}{|c|ll|}
\hline Non-verbal data & & \multicolumn{1}{c|}{ Young Adult Respondents } \\
\hline \multirow{2}{*}{ Picture 1 } & - Coca Cola encourages young people to have fun \\
& - Coca Cola promotes youth freedom \\
\hline Picture 2 & - No relation to Coca Cola \\
\hline
\end{tabular}




\begin{tabular}{|c|c|}
\hline Picture 3 & $\begin{array}{l}\text { - Coca Cola boosts our spirit up } \\
\text { - Coca Cola as a replacement for alcohol }\end{array}$ \\
\hline Picture 4 & $\begin{array}{l}\text { - Coca Cola as a means to make friends } \\
\text { - Coca Cola unifies different people } \\
\text { - No relation to Coca Cola }\end{array}$ \\
\hline Picture 5 & $\begin{array}{l}\text { - Coca Cola as a companion that creates cozy atmosphere } \\
\text { - No relation to Coca Cola }\end{array}$ \\
\hline
\end{tabular}

In perceiving non-verbal data, most of young adult respondents could see that each picture describes Coca Cola's roles in daily life. Not only physical roles, but young adult respondents also relate Coca Cola to its emotional roles such as: mood booster or companion. Some of the young adult respondents did not find any relation to Coca Cola. The writer thought that is because the respondents did not see a fitting role for Coca Cola in the picture.

\section{The analysis of perceived meanings by older respondents}

In order to answer the second research question, the writer also did her analysis on the older respondents' perceived meanings. The older respondents are classified as Respondent no 9 to 16 (R9 to R16). From the data of older respondents, the writer also discovered that some older respondents produced similar perceived meanings to each other. Therefore, the writer also formed several groups for similar perceived meanings produced by older respondents.

The analysis of older respondents' perceived meanings from the verbal data

The writer has also classified older respondents' perceived meanings from the verbal data in one table:

Table 3: Older respondents' verbal data perceived meanings

\begin{tabular}{|c|c|}
\hline Verbal data & Older Respondents \\
\hline $\begin{array}{l}\text { "Friends with } \\
\text { Stories" }\end{array}$ & $\begin{array}{l}\text { - Coca Cola encourages us to make friends and share } \\
\text { stories } \\
\text { - No relation to Coca Cola } \\
\text { - Coca Cola is a friend that refreshes us }\end{array}$ \\
\hline $\begin{array}{l}\text { "Smiles with } \\
\text { Secrets" }\end{array}$ & $\begin{array}{l}\text { - The respondents did not give any perceived meanings } \\
\text { - The words simply mean about secrets }\end{array}$ \\
\hline $\begin{array}{l}\text { "Love with } \\
\text { Refresh" }\end{array}$ & $\begin{array}{l}\text { - } \quad \text { Coca Cola produces love and freshness } \\
\text { - Coca Cola unifies differences } \\
\text { - The respondent did not give any perceived meanings }\end{array}$ \\
\hline $\begin{array}{l}\text { "Strangers with } \\
\text { Fire" }\end{array}$ & $\begin{array}{l}\text { - The respondents did not give any perceived meanings } \\
\text { - Coca Cola brings new friends } \\
\text { - Coca Cola cannot get us new friends } \\
\text { - Coca Cola is tempting }\end{array}$ \\
\hline $\begin{array}{l}\text { "Madness with } \\
\text { You" }\end{array}$ & $\begin{array}{l}\text { - Coca Cola is exciting } \\
\text { - Coca Cola as a means for friendship } \\
\text { - Coca Cola does not make you excited } \\
\text { - A situation where we get excited } \\
\text { - The respondent did not give any perceived meanings }\end{array}$ \\
\hline
\end{tabular}

In perceiving verbal data, most of the older respondents did not give any perceived meanings as they did not understand how Coca Cola can be related to the words. The writer thought that is due 
to the older respondents' not favoring Coca Cola at all in their daily lives and their belief on Coca Cola. Coca Cola is viewed as something risky for the older respondents' health. Although some of the older respondents gave perceived meanings related to Coca Cola, the perceived meanings contain doubt of how Coca Cola is shown positively in the video.

The analysis of older respondents' perceived meanings from the non-verbal data

In order for the writer to understand what the older respondents' perceived meanings are, the writer concluded their perceived meanings from the non-verbal data in one table:

Table 4: Older respondents' non-verbal data perceived meanings

\begin{tabular}{|c|c|}
\hline Non-verbal data & Older Respondents \\
\hline Picture 1 & $\begin{array}{l}\text { - The respondents did not give any perceived meanings } \\
\text { - The picture does not fit to Coca Cola } \\
\text { - The teenagers are having fun because of Coca Cola }\end{array}$ \\
\hline Picture 2 & $\begin{array}{l}\text { - Coca Cola refreshes our whole body } \\
\text { - The picture does not make sense }\end{array}$ \\
\hline Picture 3 & $\begin{array}{l}\text { - Coca Cola boosts our energy and spirit } \\
\text { - No relation to Coca Cola }\end{array}$ \\
\hline Picture 4 & $\begin{array}{l}\text { - Coca Cola deepens friendship } \\
\text { - Coca Cola is suitable to drink in certain circumstances } \\
\text { - Interesting picture } \\
\text { - Coca Cola unify differences }\end{array}$ \\
\hline Picture 5 & $\begin{array}{l}\text { - Coca Cola brings us closer to our friends } \\
\text { - The picture is not interesting }\end{array}$ \\
\hline
\end{tabular}

In perceiving the non-verbal data, the older respondents tend to give perceived meanings related to Coca Cola's freshness as freshness is what Coca Cola is mostly known for. Some of the respondents thought that the some pictures do not fit to Coca Cola or do not make any sense. In here, the writer saw that some older respondents did not get the intended symbols in the pictures.

\section{Differences between young adult and older respondents' perceived meanings}

Other than analyzing what perceived meanings that the young adult and older respondents are, the writer also extends her research to find differences between that two age groups. The writer saw that each age group has different perceived meanings from each other.

\section{The differences between young adult and older respondents' perceived meanings in verbal data}

The first difference that the writer points out is that the young adult respondents' perceived meanings contain more positive attitude toward Coca Cola than the older respondents' perceived meanings. First of all, some of older respondents got perceived meanings that Coca Cola is only a drink, nothing more than that. The writer found that some the older respondents are not fond of Coca Cola at all that they did not even recognize what Coca Cola can do for their consumers other than refreshing our body. On the other hand, young adult respondents considered the verbal data as a message from Coca Cola to their consumers. As the actors and the actresses in the video are also young adult, some young adult respondents could relate the words with their personal experiences and then, related it to Coca Cola.

The second difference that the writer points out is all of the the young adult respondents gave perceived meanings, meanwhile, some of the older respondents did not produce any perceived meanings. There are some of them who did not produce any perceived meanings as they did not quite understand the words. Despite the writer translated the words in Indonesian, some of the older respondents did not get the relation between the words. For example, one respondent did not 
understand the words "smiles with secrets" because she did not find the relation between smiles and secrets.

The writer found that the third difference is young adult respondents tend to relate the Coca Cola advertisement to their own personal experience, meanwhile, the older respondents only regarded Coca Cola as only a products made by producers to earn profit. The young adult respondents, in perceiving the verbal data, tried to relate Coca Cola with situations in their daily lives or with their friends. As for the older respondents, they did not seem to find any relation to themselves and they had a rigid view about Coca Cola.

\section{The differences between young adult and older respondents' perceived meanings in non- verbal data}

From the non-verbal data, the writer saw that young adult respondents' perceived meanings are mostly about adolescence, on the other hand, the older respondents' perceived meanings are mostly about Coca Cola's main function as a refresher. Most of the older respondents got perceived meanings that Coca Cola's role is to energize our body or to cool our body in warm weather. In contrast, young adult respondents' perceived meanings are mainly talking about how Coca Cola accompanies young generation in daily activities.

Different from young adult respondents who got perceived meanings related to Coca Cola from the non-verbal data, most older respondents did not get perceived meanings on the non-verbal data because they only thought whether the pictures are not interesting or unthinkable or unfitting to Coca Cola. Some older respondents consider certain pictures are not interesting because Coca Cola is not visible at all in the picture. Some older respondents may have thought that since this is an advertisement about Coca Cola, Coca Cola should be emphasized in the each picture. Some pictures for the non-verbal data do not contain Coca Cola. In here, it is shown that the respondents' background knowledge also plays a role in perceiving meanings. In perceiving non-verbal data, most of older respondents did not recognize some symbols in the picture because in the first place, they did not have any knowledge on signs or symbols in advertisements. As the older respondents are also businessmen and businesswomen, they felt that the advertisement is not emotionally attractive for them and they recognized the video is just another strategy of Coca Cola to appeal to the customers.

\section{CONCLUSION}

From her findings, the writer concluded that her research has revealed that age can indeed affect the process of perceived meaning. Each age group emphasizes on different things which can affect their perceived meanings. In this case, the writer sees that the young adult respondents mostly emphasized on Coca Cola's emotional roles (youth companion, entertainer, or motivator). Meanwhile, the older respondents put more attention to Coca Cola physical role (body refresher) as they did not see what Coca Cola can do for them other than to quench their thirst. Other than age, the writer saw that background knowledge also affects the respondents' perceived meanings. The writer could see that the older respondents view the advertisement differently from young adult respondents. The older respondents view Coca Cola in the video as nothing more than a profitable unhealthy product. On the other hand, the young adult respondents view Coca Cola in the video as both a product and a companion in daily lives.

\section{REFERENCES}

Berger, A.A. (2010). The Objects of Affection: Semiotics and Consumer Culture. New York: Palgrave Macmillian.

Chandler, D. (2007). Semiotics The Basics (2nd ed). London: Routledge.

Drolet, A., Williams, P., Lau-Gesk, L. (2007). Age-related differences in responses to affective vs. Rational ads for hedonic vs. utilitarian products. (http://papers.ssrn.com/sol3/papers.cfm?abstract_id=1946336) 
Fung, H. H., \& Carstensen, L. L. (2003). Sending memorable messages to the old: Age differences in preferences and memory for advertisements. (http://dx.doi.org/10.1037/0022$\underline{3514.85 .1 .163)}$

Ogden, L.C., Kit, K.B., Carroll, D.M., Park, S. (2011). Consumption of Sugar Drinks in the United States, 2005-2008. (http://www.cdc.gov/nchs/products/databriefs/db71.htm).

Schreier, M. (2012). Qualitative Content Analysis in Practice. Los Angeles: SAGE Publications, Ltd.

Staff, J. (2016). Taste The Feeling: Watch 6 Ads From Coke's New Global Campaign.

(http://www.coca-colacompany.com/stories/brands/2016/taste-the-feeling--watch-6-adsfrom-coke-s-new-global-campaign) 